\title{
Consequences of physiological heat shock beginning at the zygote stage on embryonic development and expression of stress response genes in cattle
}

\author{
M. Sakatani, ${ }^{\star} \dagger$ N. V. Alvarez, $\dagger$ M. Takahashi, ${ }^{\star}$ and P. J. Hansen ${ }^{1}$ \\ *Kyushu-Okinawa Agricultural Research Center, National Agriculture and Food Research Organization, Kumamoto, Japan 861-1192 \\ †Department of Animal Sciences and D. H. Barron Reproductive and Perinatal Biology Research Program, University of Florida, \\ Gainesville 32611-0910
}

\begin{abstract}
The goal was to understand the role of heat shock at the zygote stage in causing infertility. Culture at $40^{\circ} \mathrm{C}$ reduced the percentage of inseminated oocytes that became a morula or blastocyst by d 6 or that were a blastocyst at $d$ 8. An additional experiment was done to test whether effects of heat shock occur early in development or at the time of morula formation. Exposure to $40^{\circ} \mathrm{C}$ for $24 \mathrm{~h}$ decreased development to the blastocyst stage if exposure was at the zygote stage $[8$ to $32 \mathrm{~h}$ postinsemination (hpi)] but not if exposure occurred at the morula stage (116 to $140 \mathrm{hpi}$ ). To test effect of oxygen concentration, inseminated oocytes were cultured at $40^{\circ} \mathrm{C}$ for 12 or $24 \mathrm{~h}$ in either air $\left(20.95 \% \mathrm{O}_{2}\right.$; high oxygen) or a $5 \%$ (vol/vol) $\mathrm{O}_{2}$ environment (low oxygen) that approximates the partial oxygen pressure of the reproductive tract. Blastocyst development was reduced by $40^{\circ} \mathrm{C}$ for 12 or $24 \mathrm{~h}$ under both atmospheres and was higher for embryos cultured in low oxygen than for embryos cultured in high oxygen. Examination of cell numbers at 72 hpi indicated that heat shock reduced developmental potential of embryos by reducing competence to complete cleavage divisions after first cleavage. Changes in expression of genes involved in heat shock and oxidative stress were measured to determine whether zygotes are more susceptible to heat shock because of reduced capacity for transcription. Heat shock was performed for $24 \mathrm{~h}$ at the 1-cell stage (expression examined in 2-cell embryos) or at d 5 (examined in morulae). Heat shock increased amounts of steady-state mRNA for HSPA1A but not for HSP90AA, SOD1, or CAT. We observed a tendency for a stage $\times$ temperature interaction for HSPA1A because the difference in expression between 38.5 and $40^{\circ} \mathrm{C}$ was greater for morulae than for 2-cell embryos. The amount of HSPA1A mRNA was less for
\end{abstract}

Received September 27, 2011.

Accepted January 20, 2012.

${ }^{1}$ Corresponding author: Hansen@animal.ufl.edu morulae that were heat shocked than for 2-cell embryos cultured at $38.5^{\circ} \mathrm{C}$. Heat shock at a temperature and oxygen tension similar to those seen in vivo can disrupt developmental competence of bovine zygotes. Increased susceptibility of the early embryo compared with the morula to heat shock was not due to reduced HSPA1A mRNA because amounts were higher for 2-cell embryos than for morulae.

Key words: heat shock, embryo, oxygen, zygote

\section{INTRODUCTION}

Fertility of lactating dairy cows decreases during heat stress (Al-Katanani et al., 1999; García-Ispierto et al., 2007; Huang et al., 2008). One cause for reduced fertility lies in effects on embryonic development because experimental exposure to heat stress during preimplantation development reduces the proportion of embryos developing to the blastocyst stage (Putney et al., 1989; Ealy et al., 1993). It is likely that the block to embryonic development caused by heat stress is caused, at least in part, to direct inhibitory effects of elevated temperature on the preimplantation embryo. Exposure of cultured embryos to elevated temperatures reduced subsequent development (Edwards and Hansen, 1997; Sugiyama et al., 2003; Sakatani et al., 2004).

An important consideration in interpreting physiological significance of elevated temperature is the stage at which embryos are exposed to heat shock. It is well established that embryos at the 2- and 4-cell stage are more susceptible to elevated temperature than are embryos at the morula stage (Edwards and Hansen, 1997; Sakatani et al., 2004; Bonilla et al., 2011). In vivo, exposure to heat stress reduced embryonic development when applied at $\mathrm{d} 1$ after insemination, but not when applied at d 3, 5, or 7 (Ealy et al., 1993).

Another consideration is oxygen tension. Free radicals play an important role in mediating deleterious effects of elevated temperature on embryonic development in vivo (Ozawa et al., 2002; Matsuzuka et al., 2005) and in vitro (Sakatani et al., 2004; Sakatani et al., 2008). Most experiments on effects of heat shock on embry- 
onic development involved culture in an atmosphere of $20.95 \%$ oxygen, whereas partial oxygen pressure of the uterus is much lower, varying from 1.5 to $8.7 \%$ in the rhesus monkey, rabbit, and hamster (Fischer and Bavister, 1993). Although partial oxygen pressure has not been measured in the bovine uterus, values in the preovulatory follicle of the cow ranged from 3.9 to 9.2\% (de Castro e Paula et al., 2008). Reducing partial oxygen pressure to $5 \%$ eliminated effects of elevated temperature on the developmental potential of bovine 2-cell embryos (de Castro e Paula and Hansen, 2008).

Although the 2-cell embryo has been shown to be very sensitive to heat shock, little work has been performed to determine the sensitivity of the 1-cell zygote to elevated temperature. It is possible that, like the 2-cell embryo, the zygote is very sensitive to heat shock. Conversely, the zygote may be more similar to the maturing oocyte, where heat shock can reduce competence for subsequent development but where the magnitude of disruption is relatively small compared with that experienced by the 2-cell embryo (de Castro e Paula and Hansen, 2007; Edwards et al., 2009).

For the current series of experiments, we addressed 3 questions. The first was whether physiological heat shock $\left(40^{\circ} \mathrm{C}\right)$ would decrease the developmental competence of zygotes and, if so, whether effects of heat shock depended upon the oxygen atmosphere. The second question was to evaluate the time point in development when heat shock causes arrested development. We reasoned that identifying stages of development that are difficult for heat-shocked embryos to complete would provide clues as to the mechanism for actions of heat shock on development. Finally, we tested whether heat shock could cause the same changes in gene expression at the 1- to 2-cell stage as occur for embryos at the morula stage. The genes evaluated were superoxide dismutase $(S O D)$, catalase $(C A T)$, heat shock $70 \mathrm{kDa}$ protein 1A (HSPA1A), and heat shock protein $90 \mathrm{kDa}$ alpha, class A member 1 (HSP90AA1). Expression of the first 2 genes, which scavenge reactive oxygen species, can be increased by oxidative stress (Scandalios, 2005), whereas HSPA1A and HSP90AA1 have important roles as molecular chaperones and in preventing apoptosis from various stress conditions, including heat shock (Whitesell and Lindquist, 2005; Arya et al., 2007; Daugaard et al., 2007).

\section{MATERIALS AND METHODS}

\section{Effect of Continuous Culture at $40^{\circ} \mathrm{C}$ Versus $38.5^{\circ} \mathrm{C}$ on Embryonic Development}

A schematic diagram of the design is shown in Figure 1A. Japanese Black (Wagyu) embryos were produced in vitro following the methods of Sakatani et al. (2008) using oocytes collected from ovaries of Japanese Black females obtained from a Japanese abattoir in winter (January to March). Fertilization proceeded for $6 \mathrm{~h}$ using sperm from 1 Japanese Black bull. Afterward, cumulus cells were removed manually, and groups of 20 inseminated oocytes were cultured in $50-\mu \mathrm{L}$ microdrops of CR1aa medium (Rosenkrans et al., 1993) supplemented with $5 \%$ (vol/vol) fetal calf serum. Inseminated oocytes were assigned randomly to be cultured at either 38.5 or $40^{\circ} \mathrm{C}$ in a humidified atmosphere of $5 \% \mathrm{O}_{2}$ and $5 \% \mathrm{CO}_{2}$ (with the balance being $\mathrm{N}_{2}$ ). Stage of embryonic development was evaluated on $\mathrm{d} 2,4,6$, and 8 after insemination.

At d 8, blastocysts were processed to determine the numbers of inner cell mass (ICM) and trophectoderm (TE) cells using described previously procedures (Thouas et al., 2001). Blastocysts were incubated for up to $60 \mathrm{~s}$ in a solution of $0.1 \mathrm{mg} / \mathrm{mL}$ propidium iodide (Invitrogen, Carlsbad, CA) and 2\% (vol/vol) Triton X-100 dissolved in PBS [10 $\mathrm{mM} \mathrm{NaPO}_{4}, \mathrm{pH} 7.4$, containing $0.9 \%$ (wt/vol) $\mathrm{NaCl}$ to label TE cells. Blastocysts were then incubated in $25 \mu \mathrm{g} / \mathrm{mL}$ bisbenzimide dissolved in ethanol for $3 \mathrm{~h}$ at $4^{\circ} \mathrm{C}$. Embryos were washed in a drop of glycerol, mounted on a glass slide, and flattened with a coverslip. Images of embryos were recorded with a CCD camera (VB-7000, Keyence, Osaka, Japan) connected to a fluorescence microscope (TE-300, Nikon, Tokyo, Japan). Cell number was counted using Lumina Vision software (Mitani Corp., Fukui, Japan), where TE cells had red and blue nuclei and ICM were blue. The experiment was replicated 5 times using a total of 77 to 79 oocytes per treatment (all treatments were in each replicate). Fertilization was performed using sperm from the same bull for all replicates.

\section{Differences Between Zygotes and Morulae in the Reduction in Development Caused by Heat Shock}

The experimental design is shown in Figure 2A. Oocytes were collected from females of several nondefined breeds (including Bos taurus and Bos indicus) from an abattoir in Florida in June. Embryos were produced in vitro using procedures described elsewhere (Fields et al., 2011). Fertilization was achieved by incubation of oocytes with a pool of sperm from 3 different bulls for $8 \mathrm{~h}$. Cumulus cells were then removed and groups of 30 inseminated oocytes were cultured in $50-\mu \mathrm{L}$ microdrops of synthetic oviduct fluid (SOF)-bovine embryo 1 (BE1) medium (Fields et al., 2011) covered with mineral oil. Oocytes were randomly assigned to culture drop. Unless otherwise stated, culture was at $38.5^{\circ} \mathrm{C}$ in $5 \% \mathrm{CO}_{2}$ in humidified air. Embryos were exposed to 1 


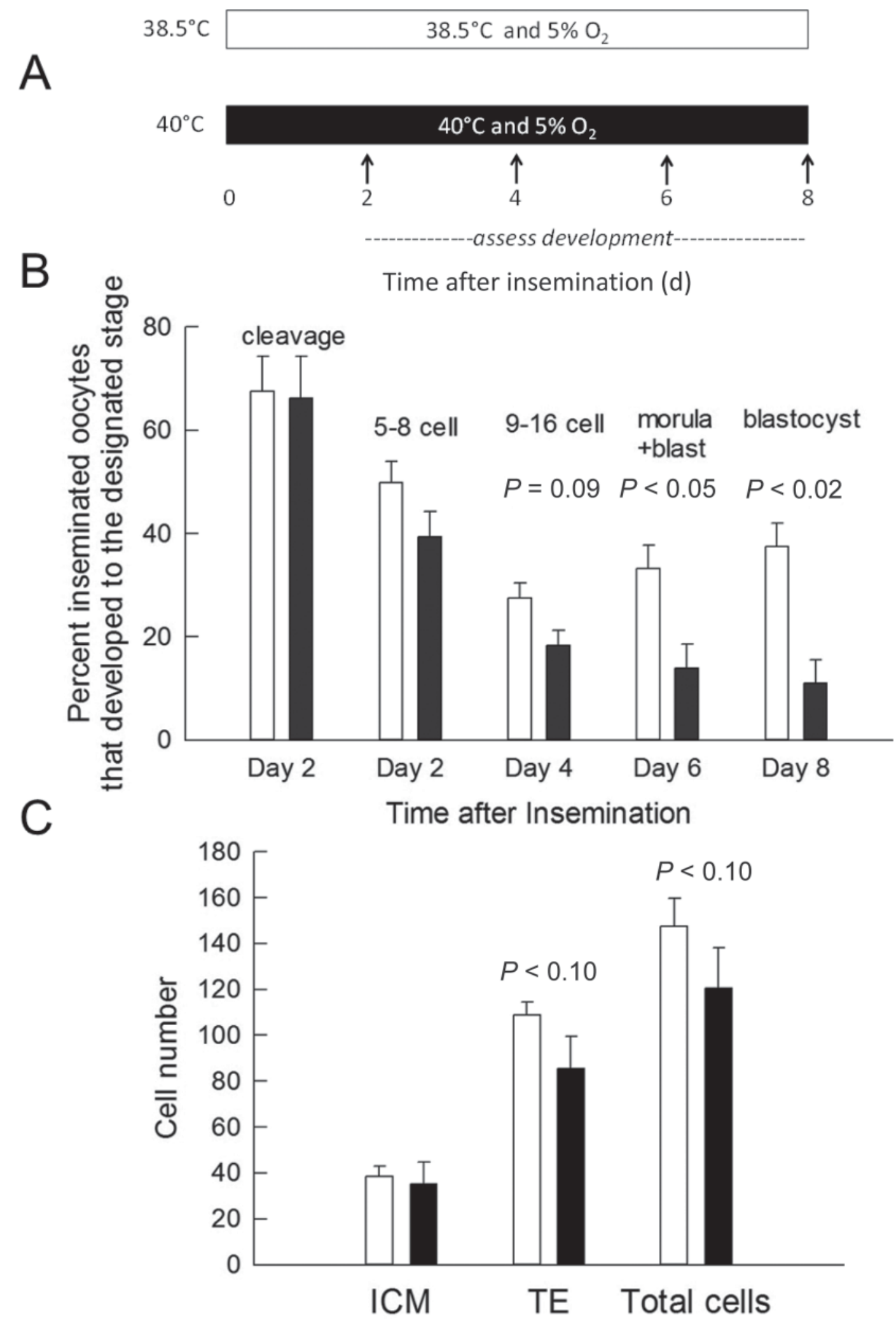

Figure 1. Effect of continuous culture at $40^{\circ} \mathrm{C}$ on embryonic development. (A) Experimental design; (B) percentage of inseminated oocytes that reached the stage listed above the bars at the day of insemination described on the x-axis; and (C) number of inner cell mass (ICM), trophectoderm (TE), and total cells for blastocysts at d 8 after insemination. Data are least squares means \pm SEM for embryos cultured at $38.5^{\circ} \mathrm{C}$ (white bars) or $40^{\circ} \mathrm{C}$ (black bars) $(\mathrm{n}=5$ replicates). The $P$-values for differences between treatments are indicated above each set of bars. 
of 3 treatments. One group was cultured continuously at $38.5^{\circ} \mathrm{C}$. Another group was exposed to $40^{\circ} \mathrm{C}$ in $5 \%$ $\mathrm{CO}_{2}$ in humidified air for $24 \mathrm{~h}$ beginning at $8 \mathrm{~h}$ postinsemination (hpi; d $0=$ insemination; zygote stage), and the third group was exposed to $40^{\circ} \mathrm{C}$ in $5 \% \mathrm{CO}_{2}$ in humidified air for $24 \mathrm{~h}$ beginning at $116 \mathrm{hpi} \mathrm{(d} \mathrm{5;}$ morula stage). After heat shock, embryos were returned to $38.5^{\circ} \mathrm{C}$ in $5 \% \mathrm{CO}_{2}$ in humidified air and cultured through d 8. Cleavage and blastocyst formation was assessed at $\mathrm{d} 3$ and 8 . Note that the $\mathrm{pH}$ did not differ

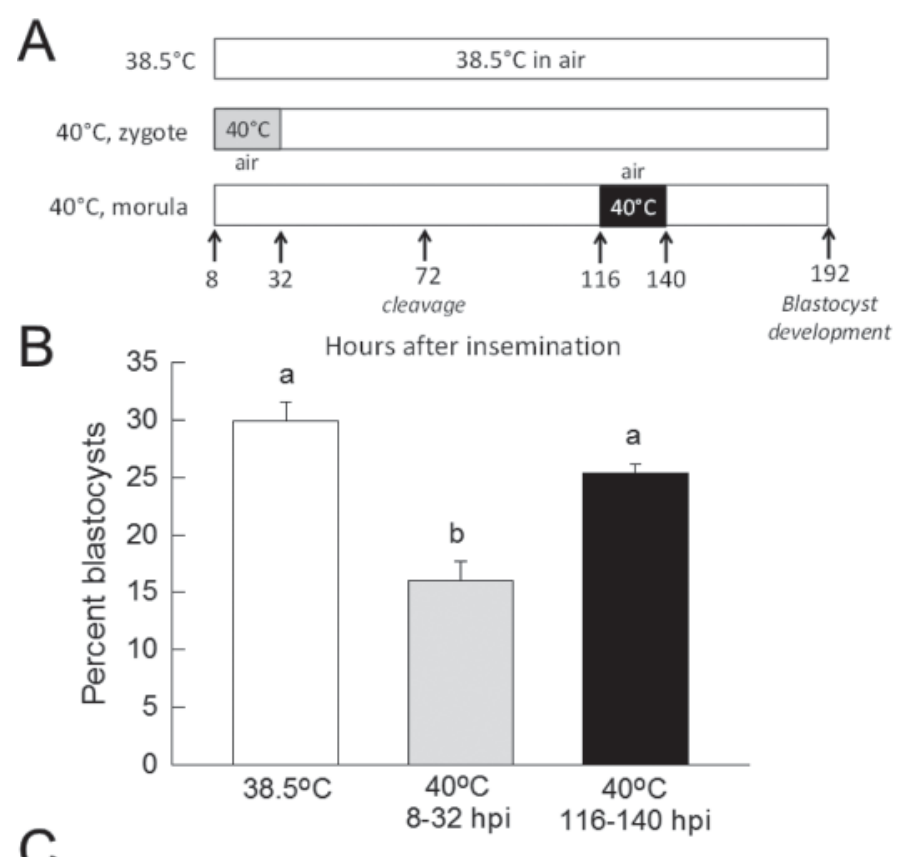

C

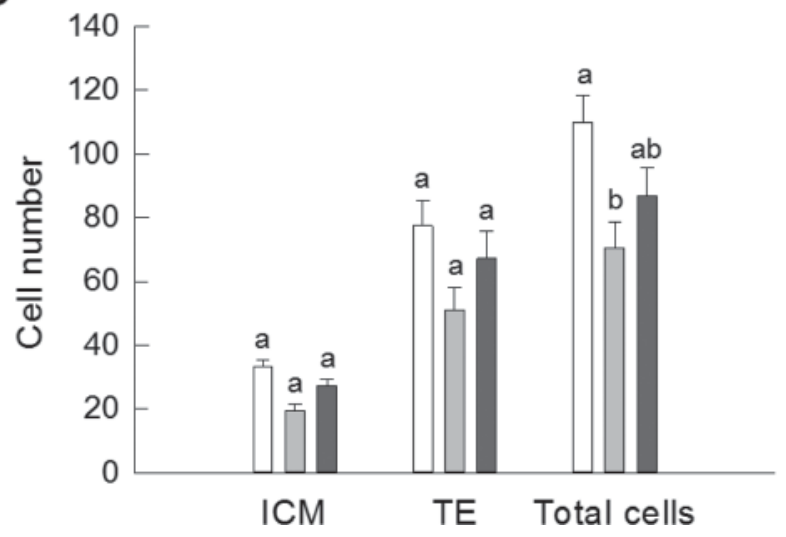

Figure 2. Differences between zygotes and morulae in the reduction in development caused by heat shock. (A) Experimental design; (B) percentage of inseminated oocytes developing to the blastocyst stage; and (C) number of inner cell mass (ICM), trophectoderm (TE), and total cells for blastocysts at d 8 after insemination. Data are least squares means \pm SEM for embryos cultured at $38.5^{\circ} \mathrm{C}$ (white bars), $40^{\circ} \mathrm{C}$ at the zygote stage (gray bars), or $40^{\circ} \mathrm{C}$ at the morula stage (black bars) ( $\mathrm{n}=6$ replicates). Bars with different letters $(\mathrm{a}, \mathrm{b})$ differ $(P<0.05)$. between media maintained at 38.5 and $40^{\circ} \mathrm{C}(\mathrm{pH}=7.45$ and 7.46 , respectively).

Blastocysts were harvested at d 8 and analyzed for differential cell count based on immunolocalization of caudal type homeobox 2 (CDX2) in TE cells. Blastocysts were fixed with $4 \%$ (wt/vol) paraformaldehyde in PBS and permeabilized with $0.25 \%$ (vol/vol) Triton X-100 in Dulbecco's PBS (DPBS) for $30 \mathrm{~min}$. After blocking with DPBS containing 5\% (wt/vol) BSA, blastocysts were incubated with mouse anti-CDX2 antibody (provided as a ready-to-use solution; BioGenex, Fremont, CA) at $4^{\circ} \mathrm{C}$ overnight. Then, blastocysts were incubated with fluorescein isothiocyanate-conjugated goat anti-mouse IgG (Abcam, Cambridge, MA) at room temperature $\left(\sim 25^{\circ} \mathrm{C}\right)$ for $1 \mathrm{~h}$. After washing, nuclei were stained with $0.1 \%$ (wt/vol) 4',6-diamidino2-phenylindole in DPBS-polyvinylpyrrolidone (PVP). Coverslips were mounted using Prolong Gold anti-fade reagent (Invitrogen) and images examined by fluorescence microscopy using a Zeiss Axioplan 2 epifluorescence microscope (Zeiss, Göttingen, Germany). Cells that were positive for CDX2 (green and blue nucleus) were considered TE and cells that were negative for CDX2 (blue nucleus only) were considered ICM. Numbers of cells were determined by analysis of photographic images using ImageJ software, version 1.45 (NIH, Bethesda, MD; rsbweb.nih.gov/ij/). The experiment was replicated 6 times using a total of 372 to 450 oocytes per treatment, with all treatments included in each replicate.

\section{Effect of Partial Pressure of Oxygen on Developmental Response of Zygotes to Heat Shock}

The experimental design is shown schematically in Figure 3A. Oocytes were collected from several nondefined breeds (including B. taurus and B. indicus) from an abattoir in Florida during June and July. Procedures for oocyte maturation were as described by Jousan and Hansen (2004). Matured cumulus cell-oocyte complexes were transferred in groups of 150 to 200 in $35-\mathrm{mm}$ plates containing $1.7 \mathrm{~mL}$ of SOF-in vitro fertilization (SOFIVF), $80 \mu \mathrm{L}$ of a solution of $0.5 \mu M$ penicillamine, 0.25 $\mu M$ hypotaurine, and $25 \mu M$ epinephrine in $0.9 \%$ (wt/ vol) $\mathrm{NaCl}$ and $1 \times 10^{6}$ Percoll-purified spermatozoa/ $\mathrm{mL}$ from a pool of frozen-thawed semen from 3 bulls. The SOF-IVF consists of $107.7 \mathrm{mM} \mathrm{NaCl}, 7.16 \mathrm{mM}$ $\mathrm{KCl}, 1.19 \mathrm{mM} \mathrm{K \textrm {KH } _ { 2 } \mathrm { PO } _ { 4 } , 1 . 1 7 \mathrm { mM } \mathrm { CaCl }}{ }_{2} \cdot \mathrm{H}_{2} \mathrm{O}, 5.3 \mathrm{mM}$ sodium lactate, $0.20 \mathrm{mM}$ sodium pyruvate, $25.07 \mathrm{mM}$ $\mathrm{NaHCO}_{3}, 0.49 \mathrm{mM} \mathrm{MgCl} 2 \cdot 6 \mathrm{H}_{2} \mathrm{O}, 6 \mathrm{mg} / \mathrm{mL}$ essentially fatty acid-free BSA, $5 \mu \mathrm{g} / \mathrm{mL}$ gentamicin, $10 \mu \mathrm{g} / \mathrm{mL}$ heparin, and $0.2 \mathrm{mg} / \mathrm{mL}$ caffeine. After $8 \mathrm{~h}$ at 38.5 $\mathrm{C}$ in a humidified atmosphere of $5 \%$ (vol/vol) $\mathrm{CO}_{2}$ in 
humidified air, inseminated oocytes were removed from fertilization wells, denuded of cumulus cells by vortexing in HEPES-Tyrode's albumin lactate pyruvate (TALP), and assigned randomly to be cultured in groups of 30 in $50-\mu \mathrm{L}$ microdrops of SOF-BE1 medium.

Embryos were cultured in 1 of 2 atmospheres in an arrangement of treatments as shown in Figure 1. The low $\mathrm{O}_{2}$ atmosphere was $5 \%(\mathrm{vol} / \mathrm{vol}) \mathrm{O}_{2}$ and $5 \%$ (vol/ vol) $\mathrm{CO}_{2}$ (balance being water vapor and nitrogen), whereas the high $\mathrm{O}_{2}$ atmosphere was $5 \% \mathrm{CO}_{2}$ in humidified air. Embryos were cultured in 1 of these 2 atmospheres at 38.5 or $40^{\circ} \mathrm{C}$ for a treatment period of 12 or $24 \mathrm{~h}$. At the end of treatment (at 20 or $32 \mathrm{hpi}$ ), all embryos were placed at $38.5^{\circ} \mathrm{C}$ and cultured through d 8 after insemination in the same atmosphere as they were exposed to during treatment. Cleavage and cell number was evaluated on d 3 after insemination and blastocyst formation was evaluated on $\mathrm{d} 7$ and 8 . The experiment was replicated 6 times using a total of 175 to 190 oocytes per treatment with all treatments in each replicate.

\section{Differences Between Zygotes and Morulae in Changes in Gene Expression Induced by Heat Shock}

The experiment was performed from May to July from embryos produced in vitro using oocytes from a Florida abattoir as described for the previous experiment. After $8 \mathrm{~h}$ of insemination, cumulus cells were removed and groups of 30 inseminated oocytes were randomly assigned to culture in $50-\mu \mathrm{L}$ microdrops of SOF-BE1 medium covered with mineral oil at $38.5^{\circ} \mathrm{C}$ in $5 \% \mathrm{CO}_{2}$ in humidified air. Groups of embryos were assigned to 1 of 4 treatments in a $2 \times 2$ arrangement of treatments with main effects of temperature (38.5 vs. $40^{\circ} \mathrm{C}$ ) and time of exposure [8-32 hpi (zygote) or 116-140 hpi (morula)]. At each time point, embryos were cultured at 38.5 or $40^{\circ} \mathrm{C}$ for $24 \mathrm{~h}$ in $5 \% \mathrm{CO}_{2}$. Immediately afterward, 2-cell embryos (8-32 hpi) or morulae (116-140 hpi) were harvested. Embryos of these stages were harvested because they represent the expected stage of development $24 \mathrm{~h}$ after initiation of treatment.

Zona pellucidae were removed by incubation in $0.1 \%$ (wt/vol) Streptococcus griseus proteinase in DPBS containing $1 \mathrm{mg} / \mathrm{mL}$ PVP. Pools of 15 (2-cell) or 10 (morulae) embryos were washed with DPBS-PVP and transferred to a $1.5-\mathrm{mL}$ tube with $50 \mu \mathrm{L}$ of extraction buffer from PicoPure RNA isolation kit (Applied Biosystems, Carlsbad, CA). Embryos were incubated at $42^{\circ} \mathrm{C}$ for $30 \mathrm{~min}$ and centrifuged at $3,000 \times g$ for $2 \mathrm{~min}$; the supernatant fractions stored at $-80^{\circ} \mathrm{C}$ until RNA extraction performed according to the manufacturer's instructions.

Following DNase treatment $(2,000$ units per $\mathrm{mL}$ of DNase I, New England Biolabs, Ipswich, MA) to remove potential genomic DNA contamination, RNA was reverse transcribed using the High Capacity cDNA Reverse Transcription Kit (Applied Biosystems) under conditions of $25^{\circ} \mathrm{C}$ for $10 \mathrm{~min}, 37^{\circ} \mathrm{C}$ for $120 \mathrm{~min}$, and $85^{\circ} \mathrm{C}$ for $5 \mathrm{~min}$. The cDNA was subjected to quantitative PCR using the CFX96 Real-Time System (BioRad, Hercules, CA) to determine expression of HSPA1A, HSP90AA1, SOD1, and CAT. Primers used are shown in Table 1. Briefly, the reaction mixture was $20 \mu \mathrm{L}$ and included $10 \mu \mathrm{L}$ of SsoFast EvaGreen Supermix $(2 \times)$, $7.2 \mu \mathrm{L}$ of diethylpyrocarbonate-treated water, $2 \mu \mathrm{L}$ of template cDNA [0.75 (2-cell) or 0.5 (morula) embryo equivalents], and $0.4 \mu \mathrm{L}$ each of forward and reverse primer (final concentration of each $=0.2 \mu M$ ). The reaction consisted of amplification at $95^{\circ} \mathrm{C}$ for $30 \mathrm{~s}$ followed by 40 cycles of $95^{\circ} \mathrm{C}$ for $5 \mathrm{~s}$ and $60^{\circ} \mathrm{C}$ for $10 \mathrm{~s}$. Each PCR reaction included a negative control in which embryo samples were included that had been subject to the reverse transcription procedure without reverse transcriptase. Each sample was replicated 2 times. The cycle threshold $\left(\mathbf{C}_{t}\right)$ values of each gene were calculated by Bio-Rad CFX Manager ver. 1.6 (BioRad). Gene expression was normalized by using the $C_{t}$ value of the reference gene $G A P D H$, and fold change of gene expression relative to values for embryos cultured at $38.5^{\circ} \mathrm{C}$ from 8 to $32 \mathrm{hpi}$ were calculated using the $\Delta \Delta \mathrm{C}_{\mathrm{t}}$ method. The experiment was replicated with 5 pools of cDNA per treatment, with each pool being generated in a separate in vitro fertilization procedure.

\section{Statistical Analysis}

A replicate was considered a single embryo production procedure using oocytes collected on $1 \mathrm{~d}$ from multiple donors and pooled before maturation. For each replicate, oocytes were randomly assigned to culture drops. Except for the first experiment, where sperm from a single bull was used throughout, each replicate used a different pool of sperm from 3 bulls to fertilize oocytes. Bulls were from various breeds, including Angus, Brangus, Beefmaster, Limousin, Simmental, Holstein, and others.

Data were analyzed by least squares ANOVA using the GLM procedure (version 9.02, SAS Institute Inc., Cary, NC). Replicate was considered a random effect and other effects were considered as fixed. Tests of significance were performed using appropriate error terms based on expected means squares. For example, the statistical model for the first experiment included effects 

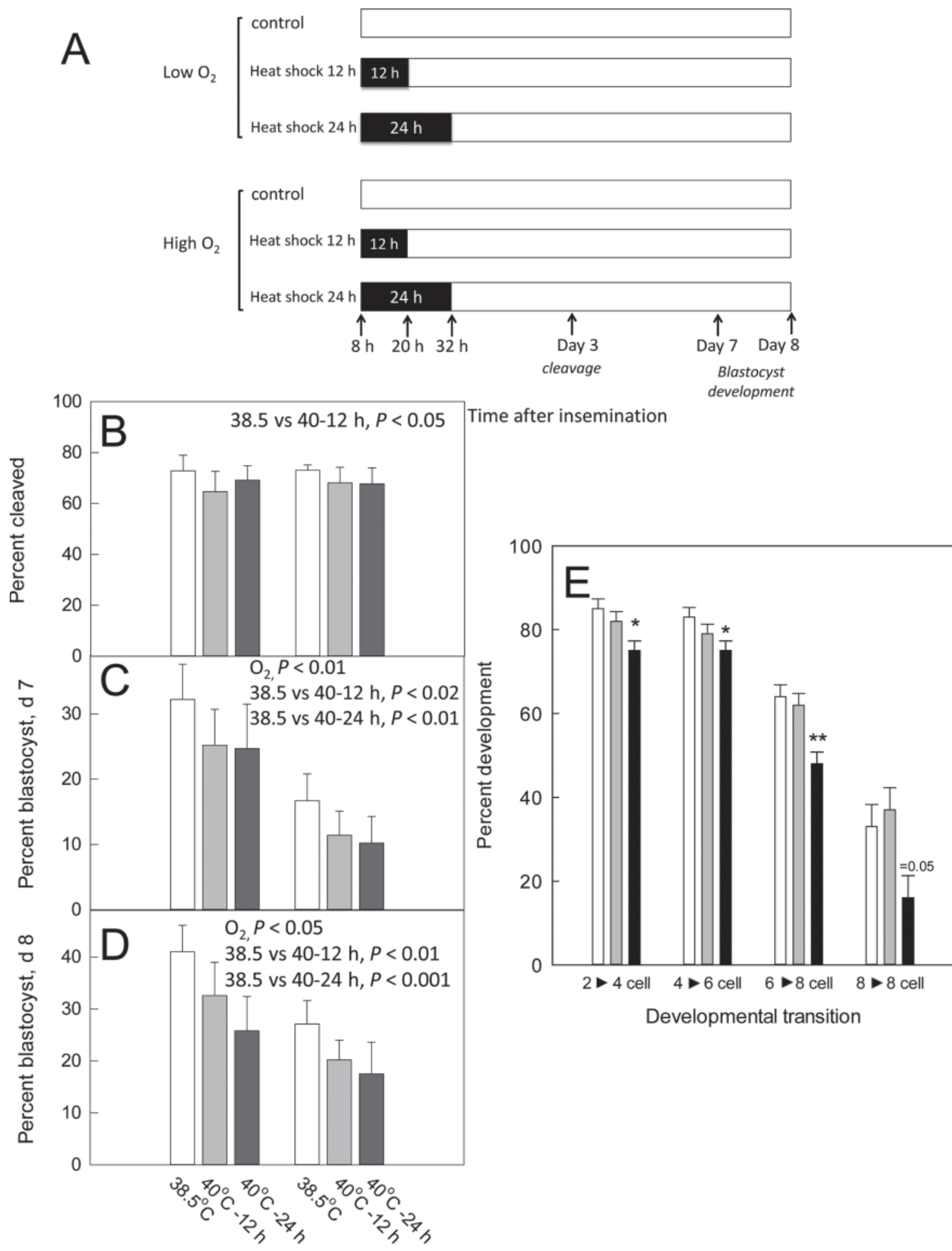

\section{Low oxygen High oxygen}

Figure 3. Interactions between partial pressure of oxygen and heat shock on developmental response of zygotes to heat shock. (A) Experimental design; (B) cleavage rate; the percentage of inseminated oocytes that became blastocysts on $\mathrm{d} 7$ (C) and d 8 (D) after insemination; and (E) the proportion of embryos reaching a specific stage of development that could advance to the next stage. For example, the proportion of 2-cell embryos that could advance to the 4 -cell stage $(2 \rightarrow 4$ cell $)$ was calculated as the total number of embryos that were $>4$ cells divided by the total number of embryos that were $>2$ cells. Data are least squares means $\pm \mathrm{SEM}$ for embryos cultured at $38.5^{\circ} \mathrm{C}$ (white bars), exposed to $40^{\circ} \mathrm{C}$ for $12 \mathrm{~h}$ (gray bars), or exposed to $40^{\circ} \mathrm{C}$ for $24 \mathrm{~h}$ (black bars) ( $\mathrm{n}=6$ replicates). Statistical significance for panels B to D is indicated by the text in the figures. For panel $\mathrm{E}$, means that differ from $38.5^{\circ} \mathrm{C}$ are indicated by symbols $(* P<0.05 ; * * P<0.01)$ or text. 
Table 1. Primer information ${ }^{1}$

\begin{tabular}{|c|c|c|c|c|}
\hline \multirow{2}{*}{$\frac{\text { Gene name }}{C A T}$} & \multicolumn{2}{|c|}{ Sequence $\left(5^{\prime}\right.$ to $\left.3^{\prime}\right)$} & \multirow{2}{*}{$\begin{array}{c}\begin{array}{c}\text { Product } \\
\text { size (bp) }\end{array} \\
229\end{array}$} & \multirow{2}{*}{$\begin{array}{l}\text { Accession no. } \\
\text { BC103066 }\end{array}$} \\
\hline & $\begin{array}{l}\text { Forward } \\
\text { Reverse }\end{array}$ & $\begin{array}{l}\text { GCAGATACCTGTGAACTGTC } \\
\text { GTAGAATGTCCGCACCTGAG }\end{array}$ & & \\
\hline$G A P D H$ & $\begin{array}{l}\text { Forward } \\
\text { Reverse }\end{array}$ & $\begin{array}{l}\text { ACCCAGAAGACTGTGGATGG } \\
\text { CAACAGACACGTTGGGAGTG }\end{array}$ & 177 & XM_002704462.1 \\
\hline$H S P A 1 A$ & $\begin{array}{l}\text { Forward } \\
\text { Reverse }\end{array}$ & $\begin{array}{l}\text { GGGGAGGACTTCGACAACAGG } \\
\text { CGGAACAGGTCGGAGCACAGC }\end{array}$ & 245 & NM_174550.1 \\
\hline HSP90AA1 & $\begin{array}{l}\text { Forward } \\
\text { Reverse }\end{array}$ & $\begin{array}{l}\text { TGCGGATCCCGTGCTAGTCCT } \\
\text { CCAGGGCGTCGGACGAGTTT }\end{array}$ & 199 & NM_001012670.1 \\
\hline SOD1 & $\begin{array}{l}\text { Forward } \\
\text { Reverse }\end{array}$ & $\begin{array}{l}\text { AAGGCCGTGTGCGTGCTGAA } \\
\text { CAGGTCTCCAACATGCCTCT }\end{array}$ & 246 & NM_174615 \\
\hline
\end{tabular}

${ }^{1} C A T=$ catalase $H S P A 1 A=$ heat shock $70 \mathrm{kDa}$ protein $1 ; H S P 90 A A 1=$ heat shock protein $90 \mathrm{kDa}$ alpha, member A1; $S O D 1$ = superoxide dismutase 1. Primers for $C A T$ and $S O D 1$ were derived from Harvey et al. (1995) and primers for HSPA1A were from Block et al. (2008).

of temperature, replicate, and temperature $\times$ replicate; temperature $\times$ replicate was used as the error term to test effects of temperature. For multiple degree-offreedom effects, means separation was performed using the pdiff procedure of SAS. Results are shown as least squares means \pm SEM. For reverse transcription-PCR data, data analyzed were $\Delta \Delta \mathrm{C}_{\mathrm{t}}$ values, and results were plotted as fold-change differences.

\section{RESULTS AND DISCUSSION}

\section{Effect of Continuous Culture at $40^{\circ} \mathrm{C}$ on Embryonic Development}

The first experiment was designed to determine whether exposure to heat shock beginning after fertilization would block development and, if so, the stage at which development was first blocked. Exposure to heat shock had no effect on the percentage of inseminated oocytes that cleaved or that reached the 2- to 4-cell stage on d 2 after insemination (Figure 1B). By d 4 of development, however, we observed a tendency $(P=$ 0.09 ) for culture at $40^{\circ} \mathrm{C}$ to reduce the percentage of inseminated oocytes that reached the 9- to 16-cell stage. Thereafter, culture at $40^{\circ} \mathrm{C}$ reduced the percentage of inseminated oocytes that were a morula or blastocyst by d $6(P<0.05)$ or that were a blastocyst at $\mathrm{d} 8(P$ $<0.02)$.

Cell number of embryos that developed to the blastocyst stage was evaluated as an indicator of blastocyst competence for subsequent development (Figure 1C). Treatment had no effect on the number of ICM cells but the number of TE cells and total cells tended $(P$ $<0.10$ ) to be lower for blastocysts that developed at $40^{\circ} \mathrm{C}$ than for those that developed at $38.5^{\circ} \mathrm{C}$. Others have reported effects of heat shock on d 0,2 , or 5 after insemination on blastocyst cell number (Paula-Lopes et al., 2003; Sakatani et al., 2004; Jousan and Hansen, 2004). Current results suggest that the reduction in blastocyst cell number caused by heat shock was primarily due to a reduction in TE cell number and not to numbers of ICM.

\section{Differences Between Zygotes and Morulae in the Reduction in Development Caused by Heat Shock}

Results from the previous experiment indicated that continuous exposure to a heat shock of $40^{\circ} \mathrm{C}$ could reduce embryo competence for development, particularly to later stages (morula and blastocyst). An additional experiment was conducted to determine whether effects of heat shock on development to these advanced stages represent actions occurring early in development or at the time of morula formation. Accordingly, embryos were exposed to $40^{\circ} \mathrm{C}$ for $24 \mathrm{~h}$ beginning at either the zygote stage (i.e., from 8 to $32 \mathrm{hpi}$ ) or morula stage of development (from 116 to $140 \mathrm{hpi}$ ). Treatment had no effect on cleavage rate, which averaged 77.4, 71.4, and $74.9 \%$ for embryos at $38.5^{\circ} \mathrm{C}, 40^{\circ} \mathrm{C}$ from 8 to $32 \mathrm{hpi}$, or $40^{\circ} \mathrm{C}$ from 116 to 140 hpi. As shown in Figure 2B, exposure to $40^{\circ} \mathrm{C}$ decreased $(P<0.05)$ the percentage of inseminated oocytes becoming blastocysts at $\mathrm{d}$ 8 after insemination if exposure was at the zygote stage (8-32 hpi) but had no effect on blastocyst development at $\mathrm{d} 8$ if occurring at the morula stage $(116-140 \mathrm{hpi})$. The increased resistance of morulae to heat shock compared with embryos at the 2- to 8-cell stage has been demonstrated many times (Edwards and Hansen, 1997; Sakatani et al., 2004; Bonilla et al., 2011).

The number of ICM and TE cells was determined by immunochemical localization of CDX2, a transcription factor whose expression is limited to TE (Kuijk et al., 2008). Representative images of immunofluorescent 

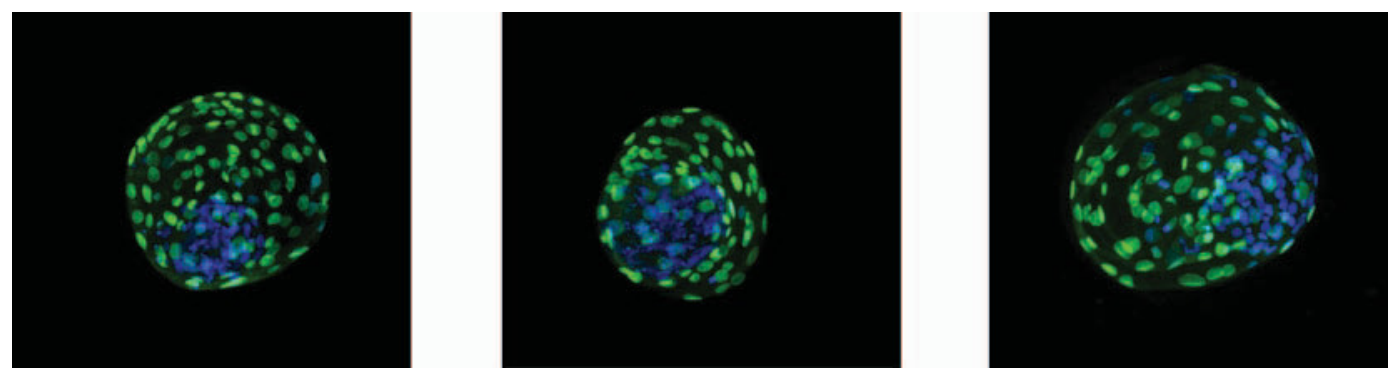

Figure 4. Representative examples of embryos labeled with anti-CDX2 (green; lighter gray) and 4',6-diamidino-2-phenylindole (blue; darker gray). Green nuclei were considered trophectoderm, whereas nuclei that labeled blue but not green were considered inner cell mass. Color version available in the online PDF.

labeling are shown in Figure 4. Culture at $40^{\circ} \mathrm{C}$ reduced blastocyst cell number when occurring at the zygote stage $(P<0.05)$ but had no significant effect when occurring at the morula stage (Figure $2 \mathrm{C}$ ). Although not significant, the reduction in cell number was more pronounced for TE than for ICM.

\section{Effect of Partial Pressure of Oxygen on Developmental Response of Zygotes to Heat Shock}

Another experiment was performed to determine whether the effect of heat shock at the zygote stage depended upon oxygen concentration. As shown in Figure 3A, inseminated oocytes were heat shocked by culture at $40^{\circ} \mathrm{C}$ for 12 or $24 \mathrm{~h}$ in either air $\left(20.95 \% \mathrm{O}_{2}\right.$; high oxygen) or a $5 \%$ (vol/vol) $\mathrm{O}_{2}$ environment (low oxygen) that approximates the partial oxygen pressure of the reproductive tract (Fischer and Bavister, 1993). A slight reduction in cleavage rate was observed for inseminated oocytes cultured at $40^{\circ} \mathrm{C}$ for $12 \mathrm{~h}(P<$ 0.05 ) but not for those cultured for $24 \mathrm{~h}$ (Figure 3B). It is unlikely that the reduction in cleavage rate for inseminated oocytes cultured at $40^{\circ} \mathrm{C}$ for $12 \mathrm{~h}$ is real given the lack of effect of 24 -h heat shock in the present experiment and the lack of effect of heat shock at the zygote stage on cleavage in the other experiments (see above). Oxygen concentration had no effect on cleavage rate.

Development to the blastocyst stage at $\mathrm{d} 7$ was reduced by exposure to $40^{\circ} \mathrm{C}$ for either $12(P<0.02)$ or $24 \mathrm{~h}(P<0.01)$ and tended to be higher for embryos cultured in low oxygen than for embryos cultured in high oxygen $(P<0.01)$. Similarly, development to the blastocyst stage at $\mathrm{d} 8$ was reduced by exposure to $40^{\circ} \mathrm{C}$ for either $12(P<0.01)$ or $24 \mathrm{~h}(P<0.001)$ and was higher for embryos cultured in low oxygen than for embryos cultured in high oxygen $(P<0.05)$. We observed no interactions, however, between temperature treatment and oxygen concentration; that is, the effect of heat shock was similar for embryos cultured in low or high oxygen.

It is well documented that a high partial pressure for $\mathrm{O}_{2}$ can inhibit embryonic development in cattle (Takahashi et al., 2000; de Castro e Paula and Hansen, 2008) as well as in other species (Goto et al., 1993; Guérin et al., 2001). However, the literature is inconsistent as to whether heat shock effects on development depend upon the partial pressure of oxygen. In one experiment with 2-cell embryos (Rivera et al., 2004), heat shock had similar negative effects on development under conditions of low or high oxygen. In another experiment, however, heat shock effects for the 2-cell embryo and morula occurred when embryos were cultured in air but not when they were cultured in $5 \% \mathrm{O}_{2}$ (de Castro e Paula and Hansen, 2008). More research is needed to determine whether interactions between heat shock and oxygen content depend upon stage of development. Nonetheless, the present results suggest that exposure of zygotes to elevated temperature in vivo could disrupt developmental potential, even though oxygen partial pressure in utero is low. Thus, the negative effect of maternal hyperthermia at $\mathrm{d} 1$ after insemination on development of embryos to the blastocyst stage (Ealy et al., 1993) could represent direct effects of elevated temperature on the zygote.

These experiments established that exposure of a zygote to physiological heat shock $\left(40^{\circ} \mathrm{C}\right)$ can compromise the ability of the zygote to develop to the blastocyst stage. At this point, however, it was not clear whether heat-shocked zygotes stop developing immediately or development becomes blocked later. Previously, it was demonstrated that 2-cell embryos exposed to heat shock of $41^{\circ} \mathrm{C}$ were able to develop normally to the 8 -cell stage but had reduced capacity to develop beyond this point (Rivera et al., 2004).

To determine when a heat-shocked zygote becomes arrested in development, we evaluated the stage of de- 
velopment to which embryos progressed at $72 \mathrm{~h}$ after addition of sperm to oocytes. In particular, the proportion of embryos reaching a specific stage of development that could advance to the next stage was calculated. For example, the proportion of 2-cell embryos that could advance to the 4-cell stage was calculated as the total number of embryos that were $\geq 4$ cells divided by the total number of embryos that were $\geq 2$ cells. We found no temperature $\times$ oxygen interaction, so data were pooled across both oxygen treatments. Heat shock for $12 \mathrm{~h}$ caused a slight reduction in cleavage rate $(P$ $<0.05$ ), whereas heat shock for $24 \mathrm{~h}$ did not affect cleavage rate (Figure 3B). Thereafter, however, embryos exposed to $40^{\circ} \mathrm{C}$ for $24 \mathrm{~h}$ at the zygote stage had reduced ability to progress to each subsequent stage (Figure 3E). In particular, embryos that reached the 2-cell stage were less likely to become 4-cell embryos if they had been heat-shocked for $24 \mathrm{~h}$ at the zygote stage $(P<0.05)$. Similarly, heat shock for $24 \mathrm{~h}$ at the zygote stage reduced the ability of embryos that reached the 4 -cell stage to develop to the 6 -cell stage $(P<0.05)$, embryos that reached the 6-cell stage to develop to the 8-cell stage $(P<0.01)$, and embryos that reached the 8-cell stage to develop past the 8 -cell stage $(P=$ 0.05). Similar results were seen for zygotes exposed to $40^{\circ} \mathrm{C}$ for $12 \mathrm{~h}$ but differences were not significant. Taken together, these results indicate that heat shock at the zygote stage reduces developmental potential of embryos to become blastocysts by reducing competence to complete cleavage divisions after first cleavage. Unlike what was reported previously for 2-cell embryos (Rivera et al., 2004), competence of the embryo was reduced by heat shock for all early cleavage divisions from the 2-cell to 8-cell stage.

\section{Differences Between Zygotes and Morulae in Changes in Gene Expression Induced by Heat Shock}

One reason why zygotes might be more susceptible to heat shock is that transcription is very limited at this stage (Memili and First, 2000; Misirlioglu et al., 2006) so that cellular adjustments to heat shock would be less extensive than for embryos that have undergone embryonic genome activation. To examine whether this is the case, we evaluated effects of heat shock initiated at either 8 hpi (when embryos were zygotes) or at 116 hpi (when embryos had advanced to the morula stage) on expression of 2 heat shock protein genes (HSPA1A and $H S P 90 A A 1)$ and 2 genes encoding for proteins that catabolize reactive oxygen species (SOD1 and CAT). Gene expression was examined immediately after $24 \mathrm{~h}$ of culture at 38.5 or $40^{\circ} \mathrm{C}$ for embryos that had devel- oped to the 2-cell stage (for embryos heat-shocked from 8 to $32 \mathrm{hpi}$; the normal stage of development at this period) or morula (for embryos heat-shocked from 116 to 140 hpi; Figure 5A).

Results are shown in Figure 5B. Steady-stage amounts of mRNA were higher for 2-cell embryos than for morula for HSPA1A $(P<0.001)$, HSP90AA1 $(P<$ $0.05)$, and SOD1 $(P<0.02)$. This pattern of declining amounts of mRNA, which has been reported previously for HSPA1A (Fear and Hansen, 2011) as well as other genes (Kues et al., 2008; Kaňka et al., 2009), probably reflects large-scale destruction of maternally derived mRNA as embryos advance through development (Gilbert et al., 2009). The one gene that did not follow this pattern was CAT. Amounts of mRNA were similar between the 2-cell and morula stages of development. Expression of $C A T$ can be increased by oxidative stress $\left(\mathrm{H}_{2} \mathrm{O}_{2}\right.$; Scandalios, 2005; de Vries et al., 2008), and perhaps oxidative stress associated with culture in air caused upregulation of this gene by d 5 after insemination for embryos cultured at both temperatures. It is also possible that the high oxygen environment in this experiment increased expression of $C A T$ and SOD1 and prevented a further increase due to heat shock.

Expression of only 1 of the 4 genes was increased by culture at $40^{\circ} \mathrm{C}$, that of HSPA1A $(P<0.02)$. Other reports also indicate an increase in steady-state mRNA and protein for this gene due to heat shock in bovine embryos as early as the 2-cell stage (Edwards and Hansen, 1996; Edwards et al., 1997; Chandolia et al., 1999). We observed a tendency for a stage $\times$ temperature interaction $(P=0.10)$ for $H S P A 1 A$. The difference in $\Delta \Delta \mathrm{C}_{\mathrm{t}}$ between 38.5 and $40^{\circ} \mathrm{C}$ was greater for morula $(-6.6$ vs. -4.6$)$ than for 2 -cell embryos $(-1.7$ vs. -1.4$)$. In addition, when data for each day were analyzed separately, the effect of temperature was significant for morula $(P<0.04)$ but not for 2 -cell embryos.

Data were interpreted to mean that heat shock could induce changes in steady-state amounts of HSPA1A at the morula stage but induction was equivocal during the period from 8 to $32 \mathrm{hpi}$ (1- to 2-cell stage). In any case, it is unlikely that morula were more resistant to heat shock than zygotes because of a greater capacity for induction of $H S P A 1 A$ transcription. Even after heat shock, the amount of $H S P A 1 A$ mRNA was less for morula than for zygotes cultured at $38.5^{\circ} \mathrm{C}$. Similarly, amounts of HSPA1A synthesized during culture at $39^{\circ} \mathrm{C}$ were higher for bovine 4-cell embryos than for morula (Edwards et al., 1997). After heat shock of $42^{\circ} \mathrm{C}$, de novo synthesis increased in embryos at both stages but values remained higher for 4-cell embryos. In a recent paper, the amount of HSPA1A evaluated by immunofluorescence was similar between 2-cell embryos and morulae (Fear and Hansen, 2011). 
A

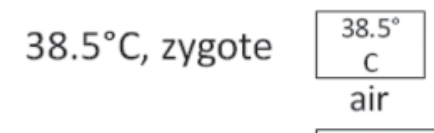

$38.5^{\circ} \mathrm{C}$, morula

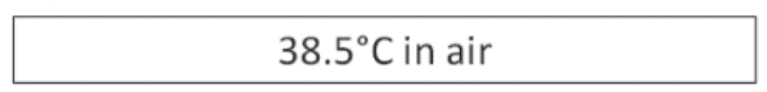

$40^{\circ} \mathrm{C}$, zygote $40^{\circ} \mathrm{C}$

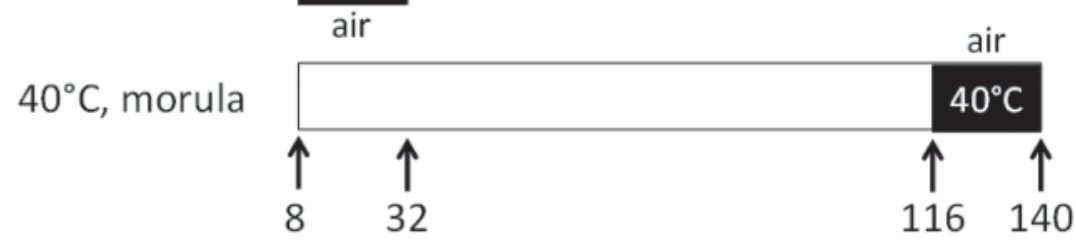

Harvest two-cells

$R T-P C R$

Harvest morulae

$R T-P C R$

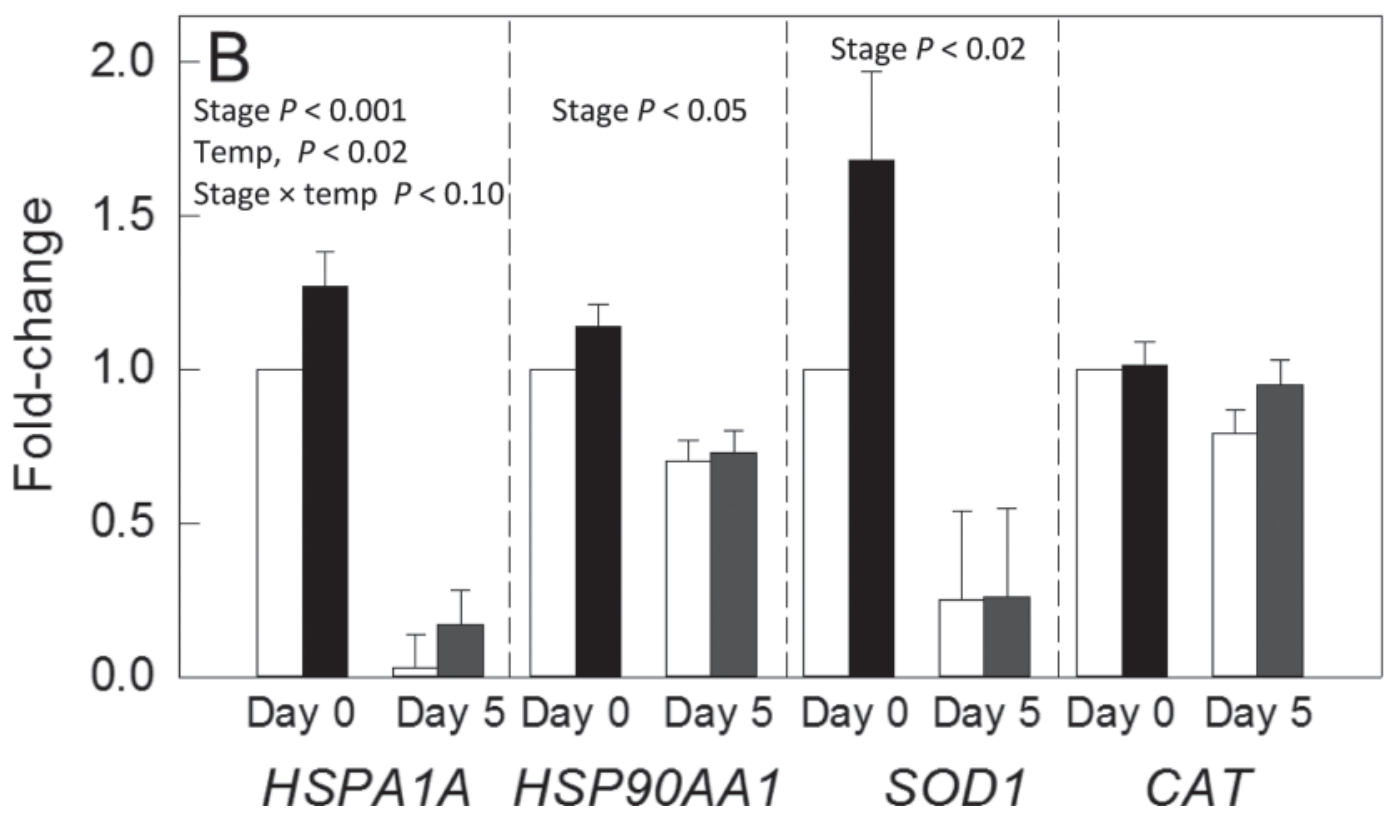

Figure 5. Differences between zygotes and morulas in changes in gene expression induced by heat shock. (A) Experimental design; note that embryos were heat shocked at either $\mathrm{d} 0$ or $\mathrm{d} 5$ and that gene expression was measured in 2-cell embryos (d 0$)$ or morulas (d 5$)$ at $24 \mathrm{~h}$ after heat shock. (B) Expression of heat shock $70 \mathrm{kDa}$ protein 1 (HSPA1A), heat shock protein 90kDa alpha, member A1 (HSP90AA1), superoxide dismutase 1 (SOD1), and catalase $(C A T)$ genes; results are least squares means \pm SEM of fold change relative to that on $\mathrm{d} 0$ at $38.5^{\circ} \mathrm{C}$. White bars represent embryos cultured at $38.5^{\circ} \mathrm{C}$, and black bars represent embryos exposed to $40^{\circ} \mathrm{C}$ for $24 \mathrm{~h}$.

The lack of effect of heat shock on expression of other genes could be due to several factors, including the fact that the heat shock used was mild. In addition, expression was measured immediately after a 24 -h period of heat shock, and expression of HSP90AA1, SOD1, or $C A T$ might have initially increased after the initiation of heat shock but have returned to baseline levels by 24 h. In addition, SOD1 and $C A T$ are increased by a high $\mathrm{O}_{2}$ tension in culture (Harvey et al., 1995; Guérin et al.,
2001) and the high oxygen conditions used here may have maximized expression of SOD1 and CAT.

\section{CONCLUSIONS}

Heat shock at temperatures and oxygen tensions similar to those seen in vivo can disrupt the developmental competence of bovine zygotes. The increased susceptibility to heat shock of the early embryo com- 
pared with the morula was not due to reduced HSPA1A mRNA because amounts were higher for 2-cell embryos than for morula.

\section{ACKNOWLEDGMENTS}

The authors thank William Rembert, Manabu Ozawa, James I. Moss, and Luciano Bonilla of the University of Florida for experimental assistance, Central Beef Packing Co. (Center Hill, FL), for donation of ovaries, and Scott A. Randell of Southeastern Semen Services (Wellborn, FL), for donation of semen. This project was supported by Agriculture and Food Research Initiative Competitive Grant no. 2010-85122-20623 from the USDA National Institute of Food and Agriculture and by the National Agriculture Food Research Organization of Japan.

\section{REFERENCES}

Al-Katanani, Y. M., D. W. Webb, and P. J. Hansen. 1999. Factors affecting seasonal variation in 90-day non-return rate to first service in lactating Holstein cows in a hot climate. J. Dairy Sci. 82:2611-2616.

Arya, R., M. Mallik, and L. C. Lakhotia. 2007. Heat shock genes-Integrating cell survival and death. J. Biosci. 32:595-610.

Block, J., C. Wrenzycki, H. Niemann, D. Herrmann, and P. J. Hansen. 2008. Effects of insulin like growth factor I on cellular and molecular characteristics of bovine blastocysts produced in vitro. Mol. Reprod. Dev. 75:895-903.

Bonilla, A. Q. S., L. J. Oliveira, M. Ozawa, E. M. Newsom, M. C Lucy, and P. J. Hansen. 2011. Developmental changes in thermoprotective actions of insulin-like growth factor-1 on the preimplantation bovine embryo. Mol. Cell. Endocrinol. 332:170-179.

Chandolia, R. K., M. R. Peltier, W. Tian, and P. J. Hansen. 1999. Transcriptional control of development, protein synthesis, and heat-induced heat shock protein 70 synthesis in 2-cell bovine embryos. Biol. Reprod. 61:1644-1648.

Daugaard, M., M. Rohde, and M. Jäättelä. 2007. The heat shock protein 70 family: Highly homologous proteins with overlapping and distinct functions. FEBS Lett. 581:3702-3710.

de Castro e Paula, L. A., and P. J. Hansen. 2007. Interactions between oxygen concentration and glucose concentration that modulate actions of heat shock on bovine oocytes during in vitro maturation. Theriogenology 68:763-770.

de Castro e Paula, L. A., and P. J. Hansen. 2008. Modification of actions of heat shock on development and apoptosis of cultured preimplantation bovine embryos by oxygen concentration and dithiothreitol. Mol. Reprod. Dev. 75:1063-1070.

de Castro e Paula, L. A., J. Andrzejewski, D. Julian, L. J. Spicer, and P. J. Hansen. 2008. Oxygen and steroid concentrations in preovulatory follicles of lactating dairy cows exposed to acute heat stress. Theriogenology 69:805-813.

de Vries, H. E., M. Witte, D. Hondius, J. M. Rozemuller, B. Drukarch, J. Hoozemans, and J. van Horssen. 2008. Nrf2-induced antioxidant protection: A promising target to counteract ROS-mediated damage in neurodegenerative disease? Free Radic. Biol. Med. 45:1375-1383.

Ealy, A. D., M. Drost, and P. J. Hansen. 1993. Developmental changes in embryonic resistance to adverse effects of maternal heat stress in cows. J. Dairy Sci. 76:2899-2905.

Edwards, J. L., A. N. Bogart, L. A. Rispoli, A. M. Saxton, and F. N. Schrick. 2009. Developmental competence of bovine embryos from heat-stressed ova. J. Dairy Sci. 92:563-570.
Edwards, J. L., A. D. Ealy, V. H. Monterroso, and P. J. Hansen. 1997. Ontogeny of temperature-regulated heat shock protein 70 synthesis in preimplantation bovine embryos. Mol. Reprod. Dev. 48:25-33.

Edwards, J. L., and P. J. Hansen. 1996. Elevated temperature increases heat shock protein 70 synthesis in bovine two-cell embryos and compromises function of maturing oocytes. Biol. Reprod. $55: 341-346$.

Edwards, J. L., and P. J. Hansen. 1997. Differential responses of bovine oocytes and preimplantation embryos to heat shock. Mol. Reprod. Dev. 46:138-145.

Fear, J. M., and P. J. Hansen. 2011. Developmental changes in expression of genes involved in regulation of apoptosis in the bovine preimplatation embryo. Biol. Reprod. 84:43-51.

Fields, S. D., P. J. Hansen, and A. D. Ealy. 2011. Fibroblast growth factor requirements for in vitro development of bovine embryos. Theriogenology 75:1466-1475.

Fischer, B., and B. D. Bavister. 1993. Oxygen tension in the oviduct and uterus of rhesus monkeys, hamsters and rabbits. J. Reprod. Fertil. 99:673-679.

García-Ispierto, I., F. Lopez-Gatius, G. Bech-Sabat, P. Santolaria, J. L. Yaniz, C. Nogareda, F. De Rensis, and M. Lopez-Bejar. 2007. Climate factors affecting conception rate of high producing dairy cows in northeastern Spain. Theriogenology 67:1379-1385.

Gilbert, I., S. Scantland, E. L. Sylvestre, C. Gravel, I. Laflamme, M. A. Sirard, and C. Robert. 2009. The dynamics of gene products fluctuation during bovine pre-hatching development. Mol. Reprod. Dev. 76:762-772.

Goto, Y., Y. Noda, T. Mori, and M. Nakano. 1993. Increased generation of reactive oxygen species in embryos cultured in vitro. Free Radic. Biol. Med. 15:69-75.

Guérin. P., S. El Mouatassim, and Y. Menezo. 2001. Oxidative stress and protection against reactive oxygen species in the pre-implantation embryo and its surroundings. Hum. Reprod. Update $7: 175-189$

Harvey, M. B., M. Y. Arcellana-Panlilio, X. Zhang, G. A. Schultz, and A. J. Watson. 1995. Expression of genes encoding antioxidant enzymes in preimplantation mouse and cow embryos and primary bovine oviduct cultures employed for embryo coculture. Biol. Reprod. 53:532-540.

Huang, C., S. Tsuruta, J. K. Bertrand, I. Misztal, T. J. Lawlor, and J. S. Clay. 2008. Environmental effects on conception rates of Holsteins in New York and Georgia. J. Dairy Sci. 91:818-825.

Jousan, F. D., and P. J. Hansen. 2004. Insulin-like growth factor-I as a survival factor for the bovine preimplantation embryo exposed to heat shock. Biol. Reprod. 71:1665-1670.

Kaňka, J., K. Kepková, and L. Němcová. 2009. Gene expression during minor genome activation in preimplantation bovine development. Theriogenology 72:572-583.

Kues, W. A., S. Sudheer, D. Herrmann, J. W. Carnwath, V. Havlicek, U. Besenfelder, H. Lehrach, J. Adjaye, and H. Niemann. 2008 Genome-wide expression profiling reveals distinctclusters of transcriptional regulation during bovine preimplantation development in vivo. Proc. Natl. Acad. Sci. USA 105:19768-19773.

Kuijk, E. W., L. Du Puy, H. T. Van Tol, C. H. Oei, H. P. Haagsman, B. Colenbrander, and B. A. Roelen. 2008. Differences in early lineage segregation between mammals. Dev. Dyn. 237:918-927.

Matsuzuka, T., N. Sakamoto, M. Ozawa, A. Ushitani, M. Hirabayashi, and Y. Kanai. 2005. Effects of heat stress on the redox status in the oviduct and early embryonic development in mice. J. Reprod. Dev. 51:281-287.

Memili, E., and N. L. First. 2000. Zygotic and embryonic gene expression in cow: A review of timing and mechanisms of early gene expression as compared with other species. Zygote 8:87-96

Misirlioglu, M., G. Page, H. Sagirkaya, A. Kaya, J. J. Parrish, and N L. First. 2006. Dynamics of global transcriptome in bovine matured oocytes and preimplantation embryos. Proc. Natl. Acad. Sci. USA 103:18905-18910.

Ozawa, M., M. Hirabayashi, and Y. Kanai. 2002. Developmental competence and oxidative state of mouse zygotes heat-stressed maternally or in vitro. Reproduction 124:683-689. 
Paula-Lopes, F. F., C. C. Chase Jr., Y. M. Al-Katanani, C. E. Krininger 3rd, R. M. Rivera, S. Tekin, A. C. Majewski, O. M. Ocon, T. A. Olson, and P. J. Hansen. 2003. Genetic divergence incellular resistance to heat shock in cattle: Differences between breeds developed in temperate versus hot climates in responses of preimplantation embryos, reproductive tract tissues and lymphocytes to increased culture temperatures. Reproduction 125:285-294.

Putney, D. J., M. Drost, and W. W. Thatcher. 1989. Influence of summer heat stress on pregnancy rates of lactating dairy cattle following embryo transfer or artificial insemination. Theriogenology $31: 765-778$.

Rivera, R. M., G. M. Dahlgren, L. A. de Castro e Paula, R. T. Kennedy, and P. J. Hansen. 2004. Action of thermal stress in two-cell bovine embryos: Oxygen metabolism, glutathione and ATP content, and the time-course of development. Reproduction 128:33-42.

Rosenkrans, C. F., Jr., G. Q. Zeng, G. T. McNamara, P. K. Schoff, and N. L. First. 1993. Development of bovine embryos in vitro as affected by energy substrate. Biol. Reprod. 49:459-462.

Sakatani, M., S. Kobayashi, and M. Takahashi. 2004. Effects of heat shock on in vitro development and intracellular oxidative state of bovine preimplantation embryos. Mol. Reprod. Dev. 67:77-82.
Sakatani, M., K. Yamanaka, S. Kobayashi, and M. Takahashi. 2008. Heat shock-derived reactive oxygen species induce embryonic mortality in in vitro early stage bovine embryos. J. Reprod. Dev. 65:496-501.

Scandalios, J. G. 2005. Oxidative stress: Molecular perception and transduction of signals triggering antioxidant gene defenses. Braz. J. Med. Biol. Res. 38:995-1014.

Sugiyama, S., M. McGowan, M. Kafi, N. Phillips, and M. Young. 2003. Effects of increased ambient temperature on the development of in vitro derived bovine zygotes. Theriogenology 60:1039-1047.

Takahashi, M., K. Keicho, H. Takahashi, R. O. Schultz, and A. Okano. 2000. Effect of oxidative stress on development and DNA damage in in vitro cultured bovine embryos by comet assay. Theriogenology $54: 137-145$.

Thouas, G. A., N. Korfiatis, A. French, G. Jones, and A. Trounson. 2001. Simplified technique for differential staining of inner cell mass and trophectderm cells of mouse and bovine blastocysts. Reprod. Biomed. Online 3:25-29.

Whitesell, L., and S. L. Lindquist. 2005. HSP90 and the chaperoning of cancer. Nat. Rev. Cancer 5:761-772. 